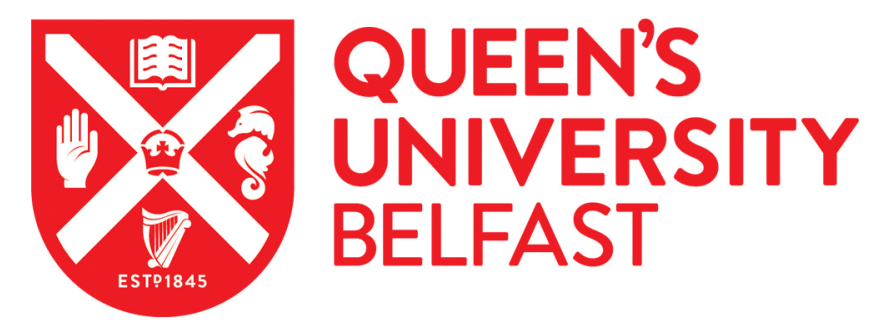

\title{
"IRISH NIGHTS": PARATHEATRICAL PERFORMANCES OF MELODRAMA ON AND OFF THE BELFAST STAGE
}

Phelan, M. (2018). "IRISH NIGHTS”: PARATHEATRICAL PERFORMANCES OF MELODRAMA ON AND OFF THE BELFAST STAGE. Theatre Survey, 59(2), 143-168. https://doi.org/10.1017/S0040557418000042

\section{Published in:}

Theatre Survey

\section{Document Version:}

Peer reviewed version

Queen's University Belfast - Research Portal:

Link to publication record in Queen's University Belfast Research Portal

\section{Publisher rights}

(c) American Society for Theatre Research 2018. This work is made available online in accordance with the publisher's policies. Please refer to any applicable terms of use of the publisher.

\section{General rights}

Copyright for the publications made accessible via the Queen's University Belfast Research Portal is retained by the author(s) and / or other copyright owners and it is a condition of accessing these publications that users recognise and abide by the legal requirements associated with these rights.

Take down policy

The Research Portal is Queen's institutional repository that provides access to Queen's research output. Every effort has been made to ensure that content in the Research Portal does not infringe any person's rights, or applicable UK laws. If you discover content in the Research Portal that you believe breaches copyright or violates any law, please contact openaccess@qub.ac.uk. 
THEATRE SURVEY

\title{
"Irish Nights": Paratheatrical Performances of Melodrama On and Off the Belfast Stage.
}

\section{Dr Mark Phelan, jan 2018}

Drama Department,

School of Arts, English and Languages

21 University Square

Queen's University Belfast

Belfast BT7 1NN m.phelan@qub.ac.uk

\begin{abstract}
This paper examines the phenomenon of "Irish Nights": performances of popular, political melodramas in Belfast that precipitated riotous paratheatrical responses from its working class audiences. Described as "melodramas within melodramas," Irish Nights were unique to Belfast given its context as a crucible of sectarian conflict in the late 1900s. However, the lack of "real" rioting outside theatres on Irish Nights suggests these in-house ructions, in a city all too often racked by very real rioting, were mock ones; rituals; part of the night out. Irish Nights are also explored in relation to Belfast's notorious reputation as a tough audience for touring theatre, and in relation to riotous rural performances by sectarian agrarian societies of historical melodramas. It argues that these melodramatic performances, though comically chaotic, were complex, paratheatrical performances of power and resistance that raise provocative questions as to the political agency of audiences: an issue often elided in Irish theatre historiography and criticism.
\end{abstract}

\section{Biography}

Mark is a Lecturer in Drama at Queen's University Belfast, where he has worked since 2001. He has published numerous articles on Irish theatre and performance and is co-editor with Des O'Rawe of Post-Conflict Performance, Film And Visual Arts: Cities Of Memory (Palgrave, 2016).- 
" 'But they wouldn't clod rivets at the stage would they?'...

'You never know what a man will do with drink and religion in him.', 1

JESSIE: Johnny Patterson the Irish Singing Clown, met his death last week in the circus ring in a most untimely accident. He was a devout patriot of his native Ireland, who nevertheless had come to believe that the one hope for that troubled isle lay in a commingling of the Orange and Green, an accommodation between the Nationalist and Unionist factions...To this end he wrote a song, 'Do Your Best For One Another' which he performed...holding in one hand a flag showing the harp and in his other, one showing the crown...

BOUCICAULT: $\quad$ Permit me to speculate - abuse hurled from both sides, faction fights ensuing, Patterson set upon by both camps simultaneously.

JESSIE: It just says there was a riot, he was trying to save the circus equipment and was struck on the head with an iron bar. ${ }^{2}$

Until relatively recently, ${ }^{3}$ melodrama has been an unfairly maligned genre of theatre history; its pejorative associations based on the prejudiced assumptions that its aesthetics of excess (in terms of its extravagant emotion, sensationalism and popularity amongst predominantly working class audiences) meant, therefore, that it was for simpletons. What Walter Benjamin excoriated as the "ancient lament that the masses seek distraction whereas art demands concentration from the spectator"4 fuelled bourgeois disdain for this theatrical form and the derision of the Theatrical Inquisitor's dismissal of melodrama as "appeal[ing] to those who wish to be amused without the slightest exertion on their part, or any exercise whatever of their intellectual powers" 5 remained the dominant critical response throughout the nineteenth century. Indeed, such views continued well into the twentieth century and certainly characterized the modernist reactions of the founding figures of the Irish national theatre in this period. Frank Fay, co-founder of the National Dramatic Society, denounced both the aesthetics of Dublin's Queen's Theatre as the "home of the shoddiest kind of melodrama", and the intelligence of its audiences who, "wouldn't, at present, understand anything else." 
Such scathing assessments of the supposed simplicity of melodrama and the "intelligence of its audiences" were, themselves, crassly simplistic, with the irony of Fay's vicious indictment of melodrama vividly apparent when one considers the complexity of "Irish Nights." Described as "melodramas within melodramas," Irish Nights were performances of popular, political melodramas in Belfast which precipitated rowdy paratheatrical responses from local audiences, and were unique to the city given its context as a crucible of sectarian conflict throughout the Irish Revival. ${ }^{8}$ In this period, the recrudescence of nationalist feeling had generated a popular new genre of Irish patriotic melodrama which was staged throughout the country; however, what distinguished performances of these political melodramas in Belfast was the ritualised rowdiness it prompted from working class audiences, who flocked to the theatre in their droves. The lack of "real" rioting outside Belfast's theatres on Irish Nights, however, suggests the off-stage performance of such inhouse ructions - in a city all too often wracked by very real rioting - were mock ones: ritualised and recreational; part of the night out.

To contextualise the phenomenon of Irish Nights, I will first examine how the advent of modern Irish drama was built on an abjection of a popular theatre practice pejoratively dismissed as simplistic and sentimental. Although this foundational myth has been debunked by scholars over the past two decades, much of this scholarship is confined to (and by) theatre in the capital. This essay, in contrast, examines how Belfast's history of sectarian conflict shaped the theatrical conditions for the reception of popular performance in such a way that the city acquired a notorious reputation as a tough audience for touring theatre.

In this essay I will also investigate Irish Nights in relation to the riotous rural performances of historical melodramas that (literally) staged the sectarian historical conflicts of the Battle of Aughrim and the Siege of Londonderry, which were wildly popular throughout Ulster in the mid-to-late nineteenth century. These amateur folk melodramas were the precursory cousins of later melodramas presented before Belfast's recently urbanised working class, though in a professional and institutional context. Drawing on Peter Brook's seminal work, I will argue that both these melodramatic practices, through their dramatic polarizations, "acted" as modes "of conception and expression... [a] fictional system for making sense of experience" 9 that helped (re)produce the violent, public, political performances of communal identity enacted outside of the auditorium, in the increasing ghettoised and politically volatile Belfast of the period.

This essay concludes with the argument that beyond their comically chaotic appearance, Irish Nights - and their rural counterparts - are extraordinarily complex, 3 
paratheatrical performances of power and resistance that raise provocative questions as to the political agency of audiences: an issue largely ignored in Irish theatre historiography and criticism. This essay finishes with a final methodological observation as to how (Irish) theatre history continues to privilege a metropolitan narrative and argues the importance of displacing and dilating this emphasis to interrogate theatrical practice beyond the capital. Critical consideration of theatre and performance in contested cities like Belfast, will not only enhance our understanding of the complexity of melodrama (both on and off the stage), but will raise profound challenges to, and rich possibilities for, the future direction of Irish theatre historiography.

\section{Irish Theatre and the Revival: Melodramatic Slatterns Vs the Modernist Muse}

Frank Fay's contempt for melodrama and its "intensely uncritical and ignorant type"10 of audience was shared by many of his Revivalist compatriots. George Moore excoriated the "illiterate puerilities" of playwrights who pandered to the base appetites of their audiences for a "trough full of guineas", abandoning high art for the "the unclean straw of melodrama and farce," their genius "submerged beneath the waves of popular taste."11 Yeats, too, abjured "melodrama and its easy victory over our sensibilities"12 and in those formative years before the founding of the Irish Literary Theatre, had praised John Todhunter's poetic drama for "appealing to that circle of cultivated people who remain faithful to the rightful Muses, and have not bowed the knee to those two slatterns, farce and melodrama."13 This axis of allegiance between Muses and slatterns, poetic drama and melodrama, tells us much about Yeats's sensibilities, although in this instance his invocation of the Muses constitutes an entirely different kind of intervention from the gods than that practiced nightly in the Queen's Theatre ${ }^{14}$ where rough divinities sat in both gallery and pit: the unwashed watching the ungodly. Indeed, the founding manifesto of modern Irish drama drawn up by the Irish Literary Theatre disavows the trope and tradition of the Stage Irishman and its bastardized Boucicaultian progeny in favour of "a Celtic and Irish School of dramatic literature" that will 
show that "Ireland is not the home of buffoonery and easy sentiment, as it has been represented." ${ }^{15}$ Over the decades this modernist privileging of high art over popular culture was reproduced by successive generations of Irish practitioners and historians, as epitomized in Hugh Hunt's history of the Abbey Theatre in which he declares that that the plays and playwrights of this Victorian period are "best forgotten." 16

A less high-minded attitude, however, was adopted by the entrepreneurial English manager of the Queen's Theatre, James W. Whitbread, who recognized the commercial potential of Irish historical melodrama in the context of surging nationalist sentiment in the 1890s. He subsequently produced, before packed houses, a series of patriotic melodramas: The Nationalist (1891); The Irishman (1892); Lord Edward; Or '98 (1894); Wolfe Tone (1898); Rory O’More (1900); The Ulster Hero (1902), The Insurgent Chief (1902), Sarsfield (1905). These plays, along with Dion Boucicault's The Colleen Bawn (1860), Arragh-naPogue (1864), The Shaughraun (1874), Robert Emmet (1884) became phenomenally popular amongst Irish audiences, both North and South, courtesy of the prodigious labours of the Kennedy Miller Combination: a company who toured these works throughout Britain and Ireland for forty weeks of the year. ${ }^{17}$ Unlike the embryonic Irish national theatre, this "very capable company of Irish players" never produced anything "as pretentious as a public manifesto for circulation to the press"; 18 an omission, which, combined with their association with exclusively melodramatic fare, contributed to their canonical disappearance as historians and critics like Hunt elevated literary drama over popular performance.

Such critical views and canonical narratives were not unique to Ireland. Indeed, various theatre historians have analysed how the advent of modern drama was predicated on the abjection of popular theatre in both Britain and America. ${ }^{19}$ In Ireland, in the past two decades, a damburst of revisionist scholarship has interrogated all aspects of the Irish Revival and has helped to dismantle the central grand narrative of Irish theatre historiography which 
consecrated the Abbey as Ireland's national theatre at the expense of any consideration of popular theatre. Stephen Watt, Nicholas Grene, Cheryl Herr and Mary Trotter's work has examined the radical as well as the reactionary nature of melodrama, the relations between its aesthetic form and ideological function, and its complex cultural legacy in contributing to the development of modern Irish drama as a whole. ${ }^{20}$ Their work has also recuperated the subgenre of Irish political melodrama and (re)positioned it as a vital precursory body of nationalist drama that preceded the more esteemed work of the Abbey Theatre; arguing that the latter was often less effective in politically galvanising its audiences. Certainly such claims support those made several decades earlier in an editorial of the Freeman's Journal:

The Irish Literary Theatre appealed to a limited audience, because it was literary. At the other end of the Irish theatrical world we have had for many years an Irish drama that was not literary in either the modern or Elizabethan acceptation of the term, but which - as we know it in the Queen's Theatre appealed very powerfully to the mind of the average man in Dublin, and especially the average working-man. Superior people sneer at what they consider to be crude and melodramatic pictures of ' 98 and other periods in Irish history which from time to time are presented in the oldest and most historic theatre in Dublin. For the most part they are critics who have never witnessed the wonderful influence which even a very plainly told story of Irish patriotism has on the minds of the honest working-men and working-women of Dublin. ${ }^{21}$

Most recently, Christopher Fitz-Simon argued that Irish political melodramas are distinct from their English and American counterparts by virtue of their nationalistic voltage, 
whereby Irish heroines are less hapless victims than aisling ${ }^{22}$ embodiments of the nation; villains are invariably treacherous agents, absentee landlords, informers or bailiffs who have betrayed their birthright; and silver-tongued servants outmanoeuvre their masters and mortal enemies with a linguistic wit as subversive as it is sophisticated. ${ }^{23}$

Such scholarship has exposed the aesthetic and ideological processes of canon formation to open up new directions in Irish theatre historiography, however, almost all of it has concentrated on melodramatic performances in Dublin. The extraordinary scenes enacted on and offstage Belfast's stages on Irish Nights when these plays were taken on tour offers further fascinating evidence as to "the complexity rather than the simplicity of this popular culture." 24 Irish Nights, as they became known, involved performances of political melodramas in Belfast's altogether more volatile playhouses where, invariably, they precipitated riotous scenes of ritualized violence from the city's warring working-class audiences. ${ }^{25}$

\section{Irish Nights in Belfast}

Irish Nights were unique to Belfast, largely because the city was a crucible of sectarian conflict throughout the latter half of the nineteenth century (more were killed in local rioting than in all of the nationalist rebellions of the nineteenth century). Although Dublin remained the administrative and commercial centre of Ireland, Belfast was its industrial base; with a smaller middle class and a significantly larger working class than the capital. It was, therefore, a city unique in the island: heavily industrialised, predominantly Protestant, prosperous and proud of its world famous shipyards and linen industry. Through trade and technology, Belfast was more integrated with Scotland and northern England than with any of its urban counterparts in the South, and "in its size, economic activities and social problems, had more in common with Glasgow or Liverpool, than with any town elsewhere in 
Ireland." ${ }^{26}$ Massive financial investment by British magnates and entrepreneurs further welded trade and political connections to Britain and the Empire and enhanced a (Protestant) colonial pride in their place in the Empire and "the enviable rank she is hastening to attain among the commercial entrepots of the British Empire."27 The corollary of this was unionist contempt for the mainly agricultural economy of Southern Ireland. As J.W. Good laconically observed, since North-East industrialists had imported their raw materials (flax and iron) and exported their final products (ships and linen) they had consequently come to regard themselves "as in Ireland rather than of it." 28

Northern industrialists and magnates, consequently, were amongst the most active opponents of Home Rule, although, unlike many of their proletarian Protestant employees, they regarded it as a threat to their economic hegemony rather than their religion. Ongoing sectarian conflict greatly benefited these wealthy ruling elites, especially against repeated efforts to organise the labour force - many of whom worked in some of the worst working conditions in the British Isles - into effective industrial action.

By the end of the nineteenth century, Belfast was the fastest growing city in the British Isles and the largest in Ireland. With this accelerated urbanisation, Belfast's Catholic population dramatically increased from $10 \%$ in 1800 to $34 \%$ in 1861 ; seismically shifting the sectarian balance of what had always been a securely Protestant city. These profound demographic changes are concomitantly reflected in the increase of sectarian rioting which was rare before 1830 , but soon after became characteristically commonplace. The increase in the Catholic population created competition for jobs and housing, and the often wretched condition of many Catholic migrants, especially during the Famine, fuelled the contempt of Protestant citizens, who regarded their destitution as yet further evidence of the baleful effects of their creed on prosperity and progress. This increase of religious and political tensions exacerbated already embittered community relations and erupted in sectarian conflict 
on a regular basis and subsequently, the two communities who were already separated in schools, churches, workplaces, increasingly became segregated residentially.

The intensity of this segregation, with its attendant sense of threat, given the contiguity of both communities, created intense loyalties to particular localities, such as the Protestant Sandy Row/Catholic Pound Loney and similarly the Shankill/Falls districts. Interfaces between these areas became ritualized flash points; sites of conflict that mutually reinforced each other's territory and identity. Indeed, the boundaries of these 'seismic zones' $^{29}$ continue to be bitterly contested (and enforced) today, where they still act as a violent source and site of sectarian conflict, reflecting how Belfast's remains a deeply divided city.

\section{If you could survive Belfast and Glasgow, you could survive anywhere.}

Popular entertainment for Belfast's new urban population was much the same as other industrial cities in mainland Britain and its theatres were dominated by touring English companies, however, local audiences were notorious for their rowdiness; prompting performers to remark: "if you could survive Belfast and Glasgow, you could survive anywhere." 30 Local author, Denis Ireland, describes Belfast as (in)famously "forbidding for the stranger or the theatrical in third rate lodgings," 31 and declared that the "sardonic humour of my native city" was most vividly evident in its theatres where it was the traditional refrain of audiences who felt:

moved at the most impressive movement of 'Hamlet', when the ghost walks upon the darkened platform at Elsinore...to shout from the gallery: 'Hi Hamlick! There's yer da. ${ }^{32}$ 
Such verbal heckles were harmless compared to those more violent interjections recorded by theatre historian, W.J. Lawrence, such as an incident in 1819, when a stone, rather than a thunderbolt, hurled by a local divinity in the gods seriously injured an actress. Later that century even the gilded splendour of Frank Matcham's sumptuous Grand Opera House could not protect performers from the gods, so that the fourth wall literally had to be materialized in the form of a giant net that was installed to catch "Belfast confetti" (steel rivets from the shipyards) and (empty) porter bottles hurled from the gallery. Belfastman Samuel Elliot recalls the rough and rowdy atmosphere of Belfast's playhouses, fondly reminiscing:

It was quite a common thing to throw an unfortunate offender or unpopular personage from the gallery to the pit and there kick and buffet him 'til almost dead, nothing apparently but the dread of the law causing them to desist... seats were torn up and thrown about through the house and on to the stage causing the speedy exit of the actor. ${ }^{33}$

One of the worst disturbances took place in 1906 (Fig. 1) in the Grand Opera House, now rechristened the Palace Theatre of Varieties, and was provoked by the seemingly innocuous act of Ahrensmayer; "a cowboy hypnotist", during which the fire proof screen had to be speedily lowered to facilitate the escape of the fleeing cowboy who left behind a scene worthy of any Wild West saloon brawl as:

[T]he crowd smashed the musicians' instruments, demolished the decorations and electrical fittings... the cinematograph apparatus was broken up and chairs flung into the stalls... The scene was one of wild disorder and the row only quelled when 50 police were marched in. ${ }^{34}$ 
Whilst such violent fracas frequently occurred in theatres throughout the British Isles, the unique in-house ructions associated with Irish Nights can be distinguished from other theatre disturbances as they were precipitated by performances of Irish political melodramas in Belfast's playhouses in a period of increasing political tension. Though such plays were wildly popular throughout the North where they were performed by professional troupes, travelling fit up companies and local communities, they were especially popular in Belfast as one local critic wearily conceded:

As for amateur representations of Arrah-na-Pogue and The Shaughraun and other Irish dramas - well, I confess in Belfast within the last half score years one and another society have produced them as often as I have fingers and toes. ${ }^{35}$

The phenomenal popularity of these plays prompted another satiric critic to claim in mockbrogue, "These dramas constichoot the foinest Iorish stage licheratoor we hev' got at the prisint moment. ${ }^{36}$ Irish Nights appealed to, and were attended by, working class audiences from both sides of Belfast's sectarian divide, with both factions well fuelled with the "liquid fire and distilled damnation" ${ }^{37}$ that the temperance campaigner, Reverend William O'Hanlon, despaired was all too prodigiously consumed by the city's lower orders. Both camps also attended the theatre equipped with instruments, flags, oranges and pockets stocked with Belfast confetti: little wonder then that one playgoer referred to Irish Nights as "melodramas within melodramas," and certainly, they can be seen as plays-within-plays, with multiple roles being performed both on and off the stage by Catholic and Protestant audiences. Perhaps the best account of an Irish Night is related in the Ulster actor, Whitford Kane's memoirs, as he recalls a performing in Boucicault's The Shaughraun: 
The play was generally turned into a battle between the religious factions. Naturally, it was a nervous play for the actors, especially those cast for the roles of the priest and young Fenian hero. The players of these characters knew that the pit would be friendly to them, but they often looked with anxious eyes at the gallery, knowing that the climax at the end of the first act would cause a hullabaloo. This occurred when the young Irish rebel was in hiding. The gallery patrons would point out to the English captain where he was concealed for they believed this was their duty as true British subjects, and, when the priest refused to disclose it, they hurled rivets and bottles at the actor. Luckily this scene happened just before the intermission and the asbestos curtain served as a timely shield for the players....and the gallery policeman would conveniently turn his back and see nothing if an odd rivet should find its way there. Cracking the skull of a fellow citizen during a performance of The Shaughraun was hardly a misdemeanour. ${ }^{38}$

His colourful account reveals the sense of ritualized theatre both on and off the stage and the symbolic, strategic and sectarian segregation of the audience with the added symbolism of the asbestos curtain, which in protecting the stage, reflected the poisoned fabric of Belfast society before it.

The popularity of Irish history and politics with Boucicault, Whitbread and others partially stemmed from the fact that it provided them with ideal melodramatic material: battlefields and the spectacular backdrop of the "Wild West" of Ireland provided sensational settings; ${ }^{39}$ informers and traitors facilitated complicated plots riddled with villainous double crosses, deceptions and dastardly asides; and the Irish pantheon of patriots provided familiar cast lists of dramatis personae that needed little introduction to local audiences who were 
equally familiar with the revolutionary rhetoric of the eponymous heroes of Wolfe Tone, Robert Emmet, Sarsfield, Lord Edward, Father Murphy which also automatically lent itself to the rarefied speech of melodrama. ${ }^{40}$ Interestingly, this recourse to history for both subject and setting by Irish melodramatists was in marked contrast to the market in England, according to Bram Stoker, the Irish author and manager of the century's most successful actor Henry Irving. Stoker reasoned that the rarity of successful historical plays in England was best explained by his compatriot playwright, Boucicault, who declared in "a beautiful Irish brogue which was part natural, part cultivated" that, "The rayson why historical plays so seldom succeed is because a normal audience doesn't go to the thaytre with its politics in its breeches pockets." ${ }^{41}$ Evidently, both Boucicault and Stoker were ignorant of how the former's plays were received by the "abnormal" audiences of Belfast whose pockets positively bulged with politics, as well as with projectiles of various kinds.

In contradistinction to Dublin, where the nationalist heroes of Wolfe Tone, Robert Emmet et al, arrived on stage to deafening cheers of "patriotic sentiment" and villains, (informers, soldiers and police), were catcalled and "hissed", these roles and receptions were reversed to riotous effect in Belfast. The city had none of the capital's (relative) political homogeneity as was evident when these productions toured North where the demographic differences of local audiences undermined the dramaturgical dialectic at the heart of these political melodramas, (in terms of good vs evil, virtue vs vice, nationalism vs unionism), and disrupted the hero-villain hierarchy of the play. For example, when the Kennedy Miller Company toured from Dublin to Belfast to stage Lord Edward, loyalists and nationalists lauded their own representatives and lambasted those of their "Other" simultaneously. One audience member describes these different reactions to the hero Lord Edward Fitzgerald, and the villain Magan: 
the Shankill hurled oranges at Tyrone Power, (who played Lord Edward) and the Falls shared its hatred of Frank Breen's informer by fierce hisses and catcalls...Now and then a scuffle would break out at the points of junction between the two. ${ }^{42}$

Lord Edward (Fig. 2) dealt with the life of Lord Edward Fitzgerald, a nationalist hero of the 1798 rebellion. However, it attracted audiences equally from the Catholic Falls and the Protestant Shankill, who were seated to the left and right respectively, replete with their flags, instruments and emblems and, more ominously, rivets purloined from the shipyards. It was a setting deemed unsuitable for the young dramatist, St. John Ervine, whose aunt who refused to take her curious nephew to an Irish Night for:

she was fearful lest there might be a row in the gallery between the Papist and the Orange corner-boys who congregated there on Irish Nights to make a demonstration of their religious beliefs: one side cheering the British authorities while the other side pelted them with orange peel and objurgations. ${ }^{43}$

Again, the drama of these occasions was well underway before the curtain had even been raised with partisan cries of "Up the Celts" and "Go on the Blues" 44 (local Catholic and Protestant football teams) providing a sectarian prelude to the play's opening tune: "The Wearing of the Green" - a nationalist ballad commemorating the 1798 Rising - that prompted the collected Catholic choirs of the Falls and the Markets to demonstrate their political solidarity, if not their musicality, as they roared along:

I met with Napper Tandy, he took me by the hand, 
And he said, "how is old Ireland, and how does she stand?"

She's the most distressful country that ever yet was seen,

They are hanging men and women there for wearing of the green. ${ }^{45}$

In response, a similarly enthused Shankill replied with a loyalist broadside of the "The Protestant Boys.” After this roisterous patriotic prelude, McCartan records how the opening of the play proceeded peaceably, as its early scenes of love and tenderness "appealed to Orange and Green alike." ${ }^{46}$ However, this temporary lull was disturbed when Lord Edward entered centre-stage to reveal his plans to liberate Ireland from English tyranny, prompting St. Peter's Brass Band, from the heart of Falls, to subsequently "[march] round the boards playing 'The Boys of Wexford"' in carnivalesque support of their patriot hero's revolutionary speech.

This nationalist performance subsequently prompted the Protestant gallery to "(stage) a melodrama of their own": ${ }^{47}$ a synchronous, symbolic and ritualized interaction between text, performance, actors and audience(s) that was an anticipated and integral part of the theatrical event. This unique and rather intimidating atmosphere prompted one audience member to wonder what the company made of their rowdy reception:

What the Kennedy Miller company - straight from the applause of the Old Queen's theatre in Dublin - thought of their noisy prelude, I could only guess; probably they were prepared for it, possibly they enjoyed it. ${ }^{48}$

Local audiences certainly enjoyed these occasions, with Hugh McCartan recalling how the West (of Belfast) would awake as the "thrilling news spread like wildfire through the Falls, the Pound Loney, the Markets.... "Lord Edward" is coming to the Royal."49 
Obviously, the tumultuous conditions and tendentious positions that accompanied these rowdy paratheatrical performances radically affected the reception of the play given its divided "interpretative communities." Indeed, the febrile atmosphere of the occasions conditioned the theatrical experience in ways that coerced individuals within both factions to decode the theatre event and its depictions of historical events in particular, partisan ways. In such a heated sectarian setting, such readings were so over-determined as to be impervious to all attempts by directors, authors or actors to influence their reading of the play/performance, with each side wholeheartedly supporting separate characters as surrogates for their own community's political beliefs. Consequently, on Irish Nights, different sections of the audience cheered at different occasions; they chanted different slogans and sung different songs in a rowdy environment that resembled that of a local football match. The physical segregation of this polarized and highly partisan audience not only minimized points of contact and conflict between both communities, but also helped reinforce how each side "read" the historical events being staged before them. Thus, this territorial segregation of communities and the tribal support for separate characters that characterized these theatrical events is significant for its deeper structural effect not only in regulating and reinforcing each faction's reading of the performance within the institutional frame of theatre building but in understanding its wider significance on the larger political stage that lay beyond the playhouse.

Consider the above in relation to the powerful final scene of Lord Edward. Commended by critics for its powerful emotional charge, the play's denouement is an anomalous exemplar of melodrama's dramaturgy. On one hand, the melodramatic trope whereby heroes are "unjustly sentenced to die (but never executed)" 50 is violated as such a scenario (even for the most sensationalist melodramatist) was impossible given the hard historical facts of Fitzgerald's execution which precluded any prospect of a last minute 
reprieve or rescue. At the same time, Whitbread squeezes all the sensation and sentimentality out of the scene that he can as Lord Edward expires, en tableau, in the embrace of his weeping wife and children, regretting the death of the officer he had killed during his arrest whilst remaining true to the cause: "I would rather be here wounded as I am, dying of neglect in this miserable dungeon, than be Pitt at the head of the British Empire.” 51

The villain, Higgins, taunts the hero over his personal and political failure, "Every stick and coin yer have will go to the King, forfeited to the State...It's death ye're feeling ...it's comin' nigh on ye now an' whin it grips ye hard and fast in its icy grasp, the Rebellion will die wid you, will die wid you." 52 Fitzgerald magnanimously forgives his foe, "I do not cannot blame you" and mournfully reflects on the failure of the rebellion, "Oh, to know that the green flag of liberty waved above our shores", before nobly parting with this paternal peroration:

Do not weep for me. To live in the hearts of those we love is not to die. Farewell, beloved wife, partner of my life's aims, joys and sorrows. Farewell brother, Aunt and trusted friend. Farewell all. Farewell. (dies) Tableau. ${ }^{53}$

It was a scene that moved one Dublin critic to opine, "no-one who has witnessed this powerful acting in the last act, will fail to remember it as one of the most emotional and artistic representations ever staged." 54 Even in Belfast, "wet eyes" were "not confined to the Falls and Pound Loney" ${ }^{\prime 5}$ (the Catholic quarters), as the sectarian divide was fleetingly bridged by dint of sheer sentiment. McCartan records that both sides left the theatre "satisfied", albeit for entirely different reasons given their divergent readings of this final scene. Loyalists were reassured by the rebellion's defeat, the dispatch of its leaders and the restoration of the ruling order; a victory which, in the context of the Home Rule crises, ${ }^{56}$ 
reassured a community that felt threatened by the growth of the Catholic population and its increasing confidence in challenging Protestant supremacy. ${ }^{57}$ For nationalist audiences, however, Fitzgerald's heroic spirit transcended the bitter reality of the rebellion's military defeat as his sacrifice was sanctified by a republican mythology that romanticized its long litany of crushing military failures, all of which were "changed utterly" into moral victories. Fitzgerald's dying declaration, "I have devoted myself wholly to her emancipation. Sacrificed wife, children, fortune, even life itself in her cause", ${ }^{58}$ and his heroic expiration en tableau in the arms of his family had not only an enormous emotional charge but a powerful political resonance given the sea-surge of renascent nationalism in the North, particularly in the run up to the extensive centenary celebrations of the 1798 Rebellion: an uprising led by the United Irishman, a separatist movement founded in Belfast.

Thus, Lord Edward valorized nationalist resistance to British rule whilst simultaneously validating loyalism's faith in the unionist status quo by reaffirming their historical superiority and present day dominance. Thus, in a very dramatic way, the reception of this play differed radically in Dublin and Belfast, with audiences in the latter appropriated these productions to stage their own paratheatrical performances of political identity.

\section{Audiences and Agency in Urban and Rural Melodramas}

Melodrama's dependence on stock characters and stereotypes particularly appealed to the divided audiences of Belfast, who, as the lives of Wolfe Tone, Robert Emmet, Lord Edward, Major Sirr played on stage, cast themselves as the "heroes" and their antagonists, both within the auditorium and onstage, as the "villains" of both the historical past and the political, performative present. The fact that melodrama banished all complexity and ambiguity from the dramaturgic struggle of the hero-villain conflict also resembled the tribal, 
territorial imperatives of identity formation in Belfast between working class unionist and nationalist communities.

Melodramatic heroes were traditionally virtuous, gallant brave, just and ultimately victorious; whereas villains incarnated the darkness and violence of the play, were attired in black; delivered dastardly asides and incorrigibly devious, feigning friendship whilst plotting feverishly in secret. In the light of this summary of the archetypal melodramatic villain, consider St. John Ervine's youthful perception of the Catholic community: "Catholic names had a sinister sound. Home Rulers were a dark, subtle and dangerous race, outwardly genial and friendly but inwardly meditating fearful things." ${ }^{59}$ In his ground-breaking study of popular theatre in Dublin, Stephen Watt argues that for the average theatregoer "history was melodrama," ${ }^{60}$ and this was even more powerfully the case for those theatre goers amongst the "Montagues and Capulets of inflammable Linenopolis." ${ }^{\prime 61}$ Melodrama's valorisation and vilification of its protagonists created a monochrome moral world that mirrored the polarized reality of Belfast. Both breathed in a world of absolutes, where character and identity were defined in rigid terms and diametrically opposed to each other. In many ways the dramaturgic structure of melodrama and "the Manichean polarities of... (its) moral world" 62 also shaped the quotidian mise en scène of life in nineteenth century Belfast in the construction and performance of power, politics, and identity.

There is one other crucially important element to these extraordinary theatrical events that needs to be considered, namely that although voluminous scholarship from various disciplines examines the socio-economic, cultural and demographic development of Belfast and those complex forces that drove the processes of polarisation that shaped the sectarian geography and identity of the city, the theatre, hitherto, has been completely neglected in all historical, anthropological, cultural, sociological and political research, even though it remained virtually the singular, secular meeting place in the whole of Belfast. ${ }^{63}$ Catholics and 
Protestants, separated, residentially, religiously, socially and spatially, attended the theatre together in droves and mixed freely together, with the notable exception of Irish Nights, when audiences self-consciously replicated the religious and political segregation extant outside the theatre within it.

Whilst the audience's political and physical polarity reflected and even reproduced the partisan politics of the play, at the same time, the separation of audiences into Catholic and Protestant sections contributed to the overall entertainment of the occasion for there is a palpable sense of the collective enjoyment of the whole spectacle, particularly in the audiences' shared anticipation, along with the hapless actors, of the fateful lines that prompted their fusillades. Indeed, in spite of the perfervid political atmosphere of these occasions, I have been unable to find any records of serious disturbance either in or outside theatres in Belfast on Irish Nights, suggesting that these in-house ructions were an accepted part of the theatrical experience. The fact that the audience corralled themselves in different areas, and brought "ammunition" with them, also suggests a local familiarity with and popular anticipation of, the likelihood of offstage dramatics. Such a supposition is supported by Whitford Kane's acknowledgement that Irish political melodramas were "always a draw in Belfast, not so much for its dramatic value, but as the audience knew it would get a chance to participate in the performance." ${ }^{44}$

It is this issue of audience agency that is crucial; all the more so in light of the historical dismissal of popular theatre and the pernicious tendency to regard its audiences as passive plebs. The subtle and complex agency of popular audiences is vividly apparent from the following incident recorded in W.J. Lawrence's unpublished Annals of the Old Belfast Stage when the celebrated actor, Edmund Kean, visited Belfast in 1823 where he performed Macbeth: 
...as he commenced one of his grandest speeches a tremendous boo came like a report of a cannon from the top gallery, and for a moment disconcerted even the great actor himself. With that eagle glance which distinguished him, he detected the author of the interruption, who happened to be a burly sweep from Smithfield. The piece proceeded and when it was over, Kean hurried to the gallery in semistage costume and met his adversary just as he was descending the stairs. Kean collared him saying, "why did you hiss me you ruffian?", "Because" coolly replied the sweep, “you put the wrong foot foremost."

Kean subsequently released his barracker, reflected on his charge and conceded the point "and putting his hand into his pocket, he gave his dusky critic a guinea." ${ }^{65}$ It is a superb example illustrating the sophistication of audiences and their specialized knowledge of performance technique, custom and practice; they were aficionados of the material stage, not passive ignoramuses. There are myriad accounts and anecdotes of similar such incidents, all of which collectively testify to the limitations of scholarship that examines theatrical performance as something created and presented in front of a passive audience. "Irish Night's" testify to theorist Tony Bennett's view that, "all texts....may be 'productively activated' during what is traditionally and inadequately thought of as the process of their consumption and reception." ${ }^{\prime 6}$

This was certainly the case with performances of political melodrama in Belfast before audiences that were malevolently partisan rather than meekly passive. Whilst Bennett was writing of the role and agency of a literary readership, his theoretical paradigm of "reading formations" can appositely be applied to the performative context of audience participation, as is somewhat comically proven by the performance of yet another Boucicault 
play, Arrah na Pogue, which was "productively de-activated" by a Belfast audience as the shipyard worker, poet, dramatist and staunch Orangeman, Thomas Carnduff recalls:

We weren't so sweet on this type of dramatic art and generally collected a party of enthusiasts to patronize the performance, not so much to welcome the artists, rather to bring the play to an early conclusion.....we filled our pockets with suitable missiles, such as bolts, rivets, half bricks and such things...we allowed the play to proceed until one of the actors burst forth into song. He managed to get through two lines of 'The Wearing of the Green'....67

This intervention resulted in the forcible physical expulsion of Carnduff and comrades by his fellow theatre-goers. This vivid, violent interaction between audience and performance and the intra-action between other audience members powerfully demonstrates the political agency of spectators who participated fully in the spectacle before them rather than being pacified by it.

It was exactly this kind audience agency and participation that left Bram Stoker ill-atease with plays that explicitly addressed political or historical issues; hence, his evident relief that his client, Henry Irving, was never able to fulfil his ambition of portraying the Irish patriot, Robert Emmet. Stoker wholeheartedly agreed with the Lord Chamberlain's intervention when it made a "request" that Irving not proceed with a production he had previously announced. The Lord Chamberlain's Office, (whose legal remit ironically did not extend to Ireland), evidently suspected a romantic melodrama portraying the life story of a romantic Irish revolutionary and performed by the stage's greatest star, could provoke political unrest: a feeling shared by Irving's Irish manager: 
the Irish question was acute. Fenianism or certain of its sequela became recrudescent. The government considered so marked and romantic a character as Robert Emmett, and with such political views portrayed so forcefully... might have a dangerous effect on a people seething in revolt. ${ }^{68}$

Stoker's reluctance to stage plays addressing contentious political or historical issues stemmed not from his political conservatism, nor any concern for his compatriots, but from his anxiety that such a charged production, the roisterous agency of audience could potentially usurp the starring role of his client: an inversion that was anathema to him. As manager of the greatest player of the British stage, Stoker sought to ensure that all elements of the theatre event were subordinated to Henry Irving's star billing. Although Robert Emmett was written as a star vehicle for his Irving, Stoker realised that such arrangements was easily threatened by the political agency of audiences:

A great political situation may like any other great existing force form a milieu for dramatic action...but where the political situation is supposed to be lasting or eternally analogous, it is apt to create in the minds of an audience varying conditions of thought and sympathy. And where these all-powerful forces of an audience are opposed they become mutually destructive, being only united into that one form which makes for the destruction of the play. ${ }^{69}$

Stoker's description of audiences as "all powerful forces": able to digest, deconstruct, even ultimately 'destroy' texts if they disagree with their politics, incisively identifies a greater sophistication of nineteenth-century audiences than they are generally accredited, as well as illustrating their critical and creative contribution to 'activating' the theatrical text in order to produce their own meaning. 
In relation to the agency and activity of audiences, I would like to briefly consider two other extraordinary melodramas that were predominantly staged in rural areas throughout Ulster and which are not examined in Watt, Herr, Fitz-Simon or Trotter's studies: The Siege of Londonderry by John Mitchelburne and The Battle of Aughrim, by Robert Ashton (Fig. 3). In spite of their phenomenal popularity, especially in Ulster, ${ }^{70}$ neither had been examined in any detail: a neglect narcotically noted by historian G.C. Duggan - "The poppy of oblivion appears to have fallen on them"71 - and only The Battle of Aughrim has received any scholarly attention. ${ }^{72}$ As may be surmised by the titles, both plays deal with the momentous seventeenth century battles that marked the defeat of Catholic armies by Williamite forces and the fact that these iconic historical events are enacted in each makes their historiographical banishment to the wings of Irish theatre history all the more ironic.

William Carleton records that both plays further fomented sectarian strife in rural Ulster, albeit it, in a radical new form as, in Carleton's words, "political rancour became dramatic". He records that both plays "were acted in barns and waste houses night after night and were attended by multitudes, both Catholic and Protestant." ${ }^{73}$ Both were widely taught in hedge schools, learned off by heart, and regularly recited and performed throughout the North. The Battle of Aughrim, in particular, was popular with the Orange Order, who enacted it in order to "show the whole world how the field of Aughrim was so gloriously won"74 although, the extent to which their world extended beyond their Catholic neighbours is doubtful. ${ }^{75}$ Attracted to the play's strongly pro-Williamite sentiments, the author being "a great enemy of Popery and wooden shoes," 76 they originally performed their play within their own community and these productions are very much performative precursors to the pageants and parades that are so much part of present-day Orange culture.

However, unlike performances of the modern day mock battle of Scarva, ${ }^{77}$ members of the Catholic community also took part in these early productions of The Battle of 
Aughrim. ${ }^{78}$ What is altogether more surprising is that these were not perforce performances as Carleton records local Catholics actually approached the Orange Order to request if they could "be allowed the favour of representing the Catholic warriors of the disastrous field". ${ }^{79}$ Subsequently, casting of the dramatis personae of Jacobite and Williamite forces, proceeded along traditional tribal lines and inevitably resulted in a sanguinary, sectarian showdown of erstwhile neighbours, roared on by their kith and kin in the audience, so that:

[W] hen they came to the conflict with which the play is made to close, [the Battle of Aughrim], armed as they were with real swords, political and religious resentment could not be restrained and they would have hacked each others' souls out had not the audience interfered and prevented them. As it was, some of them were severely, if not dangerously wounded. ${ }^{80}$

A more literal manifestation of Conor Cruise O'Brien's maxim that Irishness is the condition of being involved in the Irish situation and usually of being mauled by it, ${ }^{81}$ would be difficult to find. Subsequently, "swords were interdicted and staves substituted": an emergency health and safety measure that met with only limited success for the consequence "as might have been expected, was that heads were broken on both sides, and a general fight between Catholic and Protestant portions of the actors and the audience ensued." In spite of these minor setbacks, a "new system was adopted" with innovative introduction of cross-casting whereby Williamite characters were played by staunch Catholics, “all probably Ribbonmen”, and Jacobite characters were to be played by "the most violent Orangemen in the parish."(133) This new system initially worked, with the only act of violence involving the ejection of "an unfortunate flunkey, who had seen a play in Dublin...shouted "up with the rag,' for which, as it was supposed that he meant to turn the whole thing into ridicule, he was 
kicked out by the Ghost, who...was one of the stoutest fellows amongst them." 82 The play proceeded peaceably until the stage floor of the local barn collapsed and enmities amongst the audience members resumed as the actors' "orange and green ribbons were soon flung off as false emblems of the principles which they had adapted only for the sake of ending the play in peaceable manner." ${ }^{83}$

Carleton's two versions of these performances, (even his comically exaggerated and embellished version published in Humours) are remarkable descriptions of how traditional theatrical codes and conventions of illusion and reality, past and present, audience and actors, collapse in the heat of the moment in "acting out" The Battle of Aughrim, as atavistic animosities overwhelm the actors. It seems that the Catholics protagonists, bitterly resentful of both the triumphalist historical narrative the written text (re)imposed on them as well as the subordinate social position it reinforced, were determined to resist these roles by reversing their historical defeat to exact revenge on their contemporary enemy in the live, performative present: "Well they bate us at Aughrim" said the Catholics, "but ...we'll turn the tebles [sic] and lick them now", ${ }^{84}$ a retributive reversal that resonated with the millenarian politics of the Ribbonmen and other nationalist secret societies. Conversely, Protestant actors sought to (re)produce the play to protect and perpetuate the social order it helped shore up, which secured their superiority ever since the historic battle they were now literally re-enacting: “"We licked them before'” said the Orangemen, 'an' by japers, we'll lick them again." 85

Carleton's description of a divided community, ritually re-enacting the past to reinforce it on one side and rewrite it on the other is remarkable. All the more so when considered in relation to one of the central questions raised by Freddie Rokem in Performing History: "As we know, it is usually the victors, not the victims, who write history. The question is to what extent this is true of those who 'perform' it on the stage as well." ${ }^{86}$ These forgotten performances of The Battle of Aughrim are extraordinary examples of the victors' 
(written) history being contested (in performance) by those 'victims' they have written out of history. In these palimpsestic performances, both communities ritually (re)enacted history to simultaneously reinforce and resist the social hierarchy and political hegemony of the present. As such, these rural performances of military melodramas mirrored the violent, paratheatrical performances of identity enacted by their urban counterparts in the increasing urbanized and ghettoized Belfast of the nineteenth century.

\section{Melodramatic Formations: Playhouse and the Polis}

Melodrama's reductive absolutism and its central dramaturgical axis of virtue vs vice; good vs evil also reflected (and reproduced) the polarised sectarian processes that shaped Belfast's geography and politics in the latter nineteenth century as the political teleologies of unionism and nationalism were constructed and performed on similarly sensationalized, absolutist terms. The populist appeal of melodrama, its reliance on sensation, spectacle as well as its emotionally charged speech very much resembled the demagogic rhetoric deployed by Belfast's street preachers and political leaders as they sought to mobilize the masses throughout the nineteenth century. Accordingly, it seems astonishing that such strident, sectarian demonstrations of political allegiance and religious animosity, made in such close proximity to one another on Irish Nights did not generate far greater violence.

One explanation is that as a venue, the official auditorium provided a different spatial and temporal context from the streets outside; one which helped to- literally and figuratively - contain its audience. Such a "safety valve" thesis is supported by historian D.A. Reid who suggests that "apart from the hustings, the theatre was perhaps the last location where an eighteenth century commotion could still occur" ${ }^{\prime 87}$ given that it was a public forum which facilitated expressions of distress from the downtrodden sections of society. Certainly, the lack of any serious disturbances on Irish Nights outside theatres in Belfast- a city, regularly 
racked by very real rioting - indicates that they did act as a safety valve and the fact that only "a few cracked heads" were incurred suggests these "battles between religious factions" were mock ones, rituals, and part of the night out.

Indeed, there is a long history of political disturbances at the theatres in Ireland, most notably by the infamous case of the Orangemen who rioted in Dublin's Theatre Royal in 1822, hurling wood and oranges at Viceroy Wellesley to demonstrate their displeasure at his administration's movement towards agreeing to introduce Catholic Emancipation. Mary Condon describes how the theatre was packed with Orangemen, all of whom met beforehand in Ship Street Orange Lodge where they were "supplied with whiskey and bludgeons." 88 Political placards were also brought to the theatre and the riot commenced when the band began to perform "God Save the King" at the end of the play.

The deliberate selection of the theatre as the venue to target the Viceroy dramatically illustrates how the theatre also operated as a public stage for the expression of political discontent and indeed there have been also many cases in Belfast of the theatre being used for similar paratheatrical political performances ${ }^{89}$ As Christopher Morash highlights in his vivid survey of the Irish stage, the theatre had long enjoyed a "legal status... as a place of public protest" $" 90$ and the prolific number of protests, and disturbances that transpired in nineteenth century's playhouses were events that were tolerated by civil and legal authorities. Official recognition of this role was actually enshrined in law as was reflected by the fact that the legal defence for these Orangemen, "based its case on the theory that a disturbance at the theatre was not a breach of the peace": ${ }^{91}$ a legal argument confirming the unique sociopolitical position of theatre and illustrating rather remarkable levels of tolerance for such practices in an increasingly strict age.

In fact, as an institution, theatre was unique in that it straddled two vying, political cultures: that of the eighteenth century's riotous public protest and the nineteenth century's 
rigid social control. It was able to accommodate both given its particular position in society as a "closed" or only "semi-public" arena wherein "social disruption could occur without necessarily having implications for the whole social order."92

\section{Staging the Nation?}

And yet, as Lionel Pilkington argues, one of the core objectives underpinning the newly emergent Irish national theatre - as conceived by its aristocratic founders - was the "enticing prospect of social consensus" wherein nationalist and unionist spectators "were agreed...[and] would behave not like a crowd, but like individual citizens" 17. For this to happen though, the roisterous atmosphere of the nineteenth-century playhouse would have to be quelled for if its rowdy spectators and their politicized interactions were to be transformed into passive citizen-subjects. Indeed, in its own manifesto, the Irish Literary Theatre stated it sought an "audience trained to listen" and sought to disciplinary processes of modernist practice dovetailed with the bourgeois processes of nation-making and cultural modernization, ,, were mob translated into people,in a national theatre that would represent "a desired political and social consensus": one in which those features of Irish life "recalcitrant to modernity- issues such as agrarian insurgency, the 1798 rebellion, or to fold beliefs, practices and superstitions of the peasantry" could be repudiated if they were not conducive to its project of cultural modernization and nation building which protected their privileged social position.

IN many ways, this "theatre of political citizenship" ran concurrent with the embourgeoisement of audiences in this period.
Commented [MP1]: Recent scholarship has helped to decommission the dominant historiographical narrative of the Irish Revival as well as its dismissal of the popular stage and concomitant privileging of modernist theatre practice. This work has debunked the foundational myth of modern Irish drama that there was no indigenous theatrical tradition before the advent of Abbey: ${ }^{1}$ an historiographical narrative that placed the role of the theatre centrestage it's the national project of nation making. 
In establishing the importance of the popular stage in this crucial period of Irish history, further work is needed to explore the ways in which audiences were positioned - and conditioned - to play the role of spectator-citizens for as Lionel Pilkington argues this

Irish political melodramas were not so much a medium for social protest or political mobilization but a site of modernisation as the national theatre sought to 'cultivate' its audiences, As Lionel Pilkington brilliant explore, this was a process though which aristocratic founders of the national theatre sought to reposition themselves and inthis way thes disciplinary processes of theatrical modernism and nation making dovetailed with each other in their drive for. Through this historiopgrapgical narrative of the Reviavlh has eben challenged and caon changed... the theatre's role in staging the nation remains hegemonic one, however, as

in this study sought exo reveal limitations of such accounts modern Irish theatre and its attendant historiography as any consideration of the febrile atmosphere of Belfast's playhouses and its fissiparous working-class audience provided a counter public sphere with the politicized responses of local audiences inimical to those encountered in the capital. This working-class counter-public which attendant Irish Nights was indifferent to Irish modernist practice $^{1}$ an couldn't be easily assimilated into the nationalist narrative of nation, that these patriotic melodramas and the later fare of the national theatre sought to produce - both on and off stage.

on the role and agency of the audience during performances of Irish melodrama.

\footnotetext{
${ }^{1}$ See my article on 'The Critical "Gap of the North": Nationalism, National Theatre, and the North', Modern Drama Vol. 47, No. 4, 2004, pp. 594-607.
}

\begin{tabular}{|c|}
\hline \\
\hline $\begin{array}{l}\text { Commented [MP3]: Second, the kind of nation and feelings } \\
\text { about nation that are played out by the Belfast audiences' activation } \\
\text { of melodrama through their participation might be a nation that } \\
\text { arrives as already contested, the site of struggle and even violence, } \\
\text { rather than the kind of coherence towards which more conscious } \\
\text { (bourgeois) nation-making projects in the theatre might be aiming. } \\
\text { And that in this instance melodrama does not provide the kind of } \\
\text { satisfying resolution in favour of one side (the good) with which we } \\
\text { might normally associate it, but, at least in some of the cases you } \\
\text { discuss, actually holds open, renews, re-activates its own black-and- } \\
\text { white conflicts. It is a more unstable, less consensual form, at least } \\
\text { in its activation by Belfast audiences, than it is routinely assumed to } \\
\text { be. }\end{array}$ \\
\hline
\end{tabular}


George Moore, who played such a prominent role in Irish Literary Theatre, declared in the foreword to his play, The Bending of the Bough (1900) that, "[t]he same audience goes everywhere, and the same fare is consequently served everywhere at the same prices." 93 However, as I have sought to argue here, this is evidently untrue as exemplified in the different receptions of Irish political melodrama in Dublin and Belfast: two cities which, as Ulster novelist George Birmingham wearily averred, "are very little more than a hundred miles apart, yet I suppose that Manchester and Bombay are not more separated in spirit."1 Audiences are never homogeneous, though this assumption underpins much Irish theatre historiography, ${ }^{94}$ it could be argued that Irish theatre historians and scholars have long helped reinforce Yeats et al.'s modernist mission in removing the political agency of audiences. The abjection of popular theatre with the advent of modern Irish drama and the embourgeoisement of theatre audiences in the twentieth century, was a process that sought to silence audiences in darkened auditoria and to separate them from onstage action; leaving them staring at the light, supine and susceptible. Pacifying and positioning audiences in this way predisposed them to read the spectacle before them in certain ways, whilst concomitantly restricting their modes of response, all of which eroded their political agency, rendering them passive spectators rather than rowdy participants (Fig. 3).

As the overwhelming majority of Irish historians and critics have concentrated on twentieth century Irish theatre (and primarily concentrate on the national theatre in Dublin), it is perhaps unsurprising that the role and agency of audience- so prominent in the nineteenth century playhouse- has been relegated and has received so little scholarly attention. Indeed, the success of modernism in removing the rowdy, participative element of the nineteenth century theatre and controlling and containing audience agency within the new contract of modernist/realist theatrical practice can arguably be measured by their continuing "silence" in Irish Theatre Studies. 
This neglect, however, has been to the detriment of the discipline as a whole as the question of audiences' political agency is crucial, not only for any investigation of the (re)production and reception of dramatic texts, but for the whole project of staging the nation. After all, the very fact that theatre was used as an ideological apparatus to represent, or rather, invent, the Irish nation fundamentally calls into question the role of the people/spectators: were they passive audiences or active agents in this process? As Loren Kruger inquires "is the audience spectator or participant? incoherent crowd or mature nation?" and does this "call for participation or simply assent?"95 When such questions are considered in relation to audience dissent, as I've tried to consider here, these disciplinary processes and positions shaped by an embryonic national theatre become exponentially all the more complicated.

In light of this, Irish Nights in Belfast - and the folk melodramas that are their rural counterparts - should never be merely regarded as comically chaotic theatre events, but as complex, paratheatrical performances of power and resistance. Indeed, when we move beyond the surface simplicity of these melodramatic texts to examine them in their complex historical and geographical contexts, as well as the "play-full" interplay of the material stage and audience agency, an entirely new range of meaning is unleashed.

Fig. 1. Irish Independent Saturday 3 February 1906 


\section{WILD SCEEE IN BELFAST}

\section{AUDIENCE STORM}

THE STAGE.

PGRHITURE ALL SMASHED.

A HYPNOTIST'S TRICK

CAUSES THE

TROUBLE.

GHAIRS FLORG FROM GALLERT.

POLICE CLEAR THE HOUSE. 
Fig. 2 Playbill for Lord Edward; or '98 by J.W. Whitbread.

Image courtesy of the Linen Hall Library, Belfast.

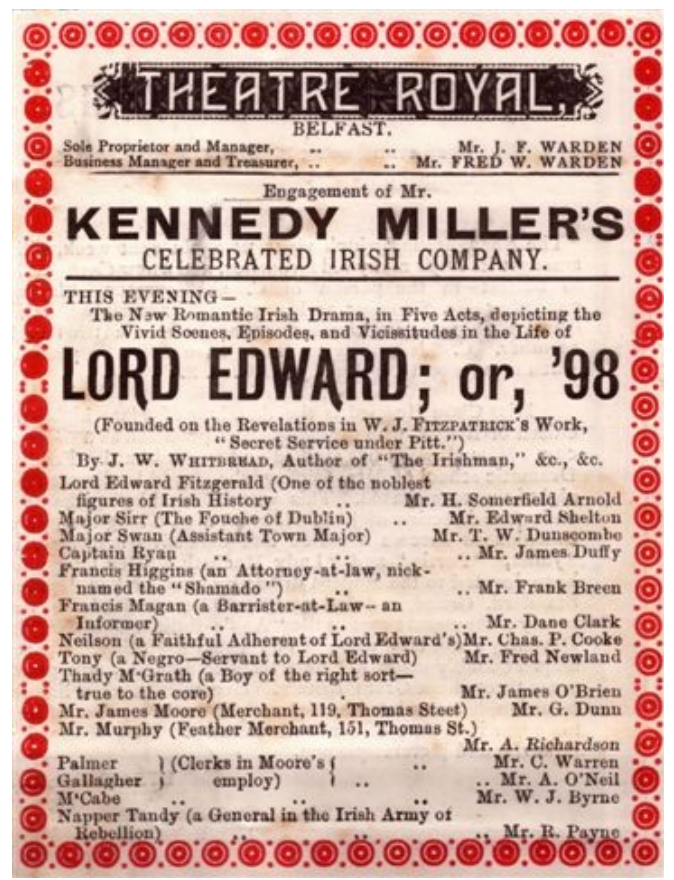

Fig. 3 John Mitchelburne and Ireland Preserved: The Siege of Londonderry and Battle of
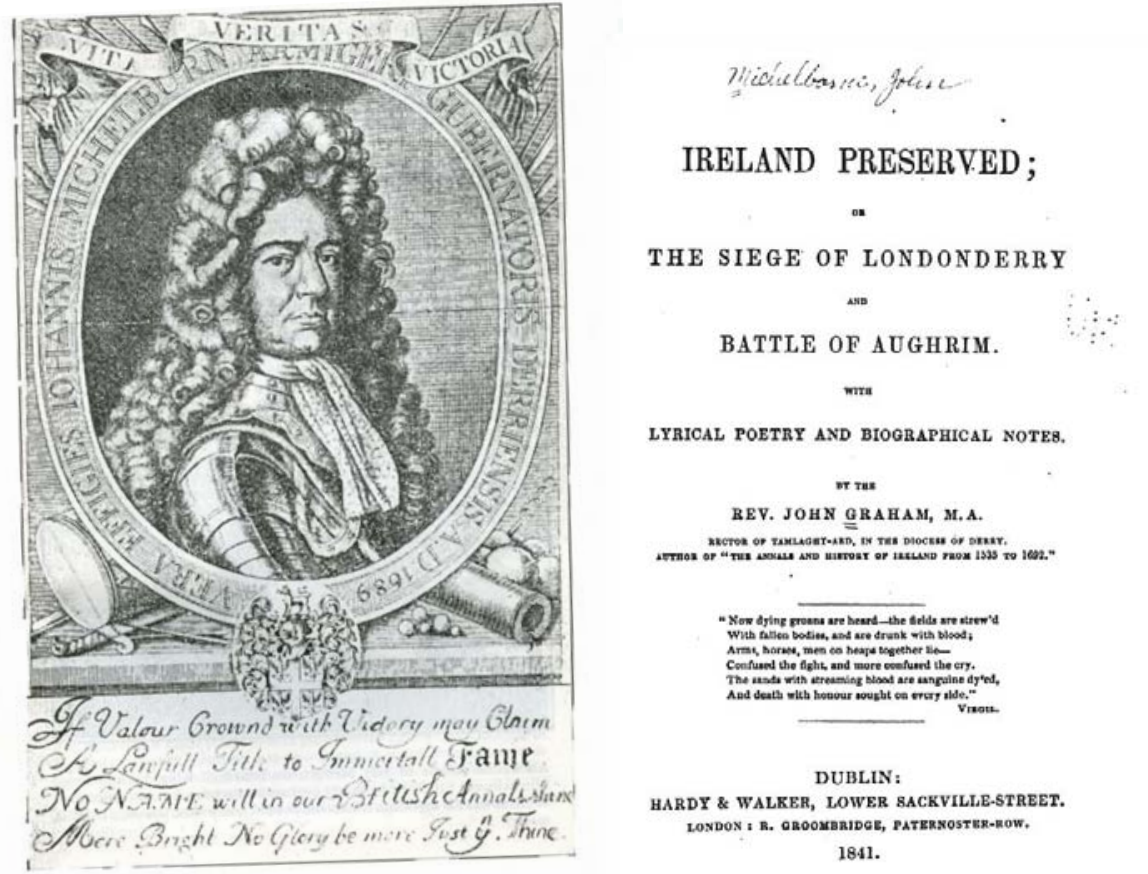
Fig. 4 Jack B. Yeats, Willy Reilly at the Old Mechanics' Theatre

Depicting a performance at the Old Mechanics' Theatre, which later became the Abbey, this fascinating painting depicts Jack Yeats's attraction to the same popular theatrical forms that were anathema to his brother William. Watercolor, Courtesy of the Abbey Theatre.

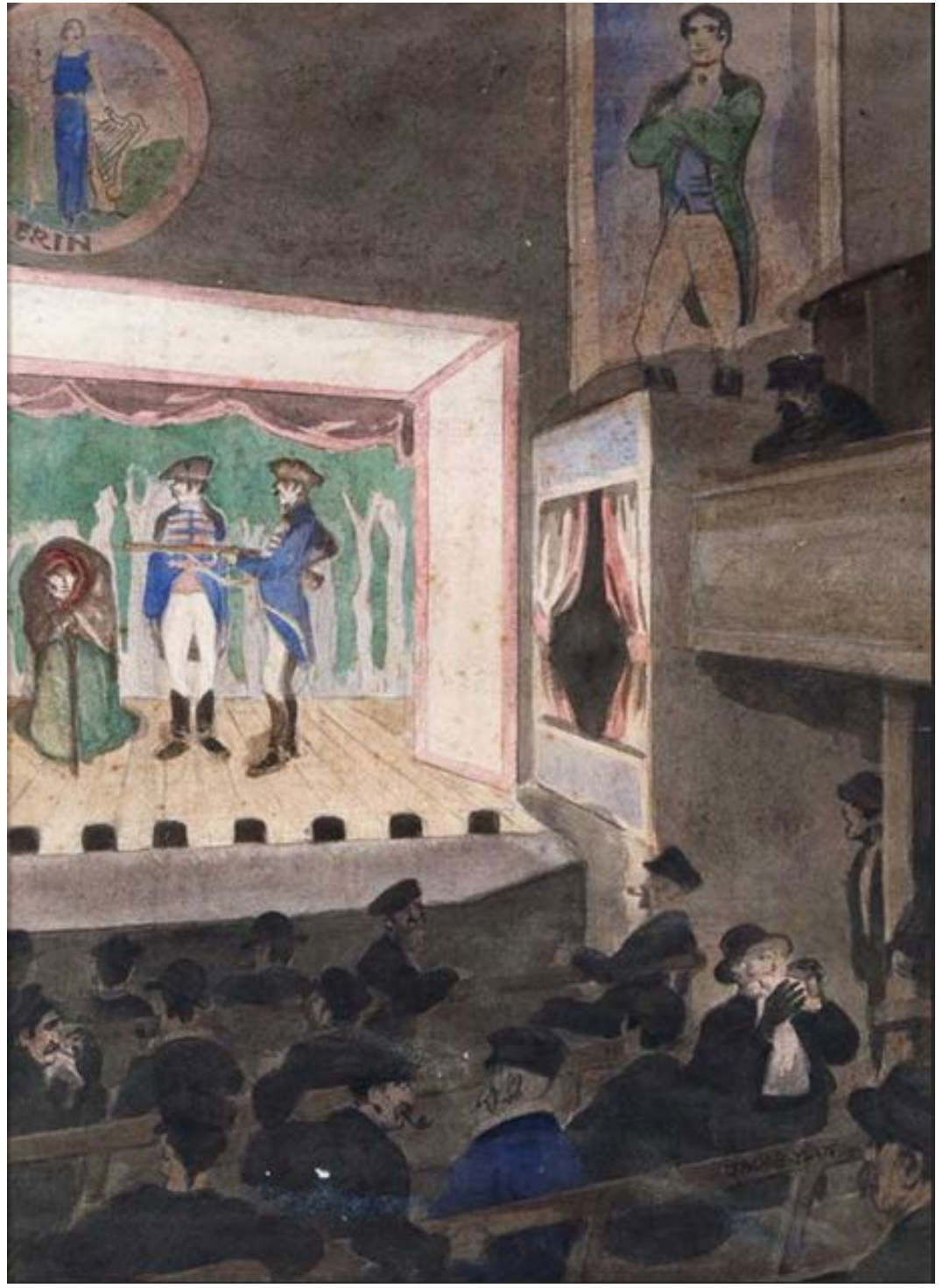




\footnotetext{
${ }^{1}$ St John Ervine, The Theatre in my Time (London: Rich \& Cowan, 1933), 15.

${ }^{2}$ Stewart Parker, Heavenly Bodies, in Plays: 2 (London: Methuen, 2000), 88.
}

${ }^{3}$ Peter Brooks' seminal The Melodramatic Imagination: Balzac, Henry James, Melodrama, and the Mode of Excess (New Haven, Conn.: Yale University Press, 1976), was the first serious study to theorise the genre and its impact was transformative, on several different fields of scholarship. It precipitated a new wave - if not a field in itself - of melodrama studies: see Michael Booth, Victorian Spectacular Theatre, 1850-1910 (London: Routledge, 1981) and Theatre in the Victorian Age (Cambridge: Cambridge University Press, 1992); Jacky Bratton, New Readings in Theatre History (Cambridge: Cambridge University Press, 2003); Jacky Bratton, Jim Cook, Christine Gledhill, eds., Melodrama: Stage, Picture, Screen (London: British Film Institute, 1994); Jim Davis and Victor Emeljanow, Reflecting the Audience: London Theatre-Going, 1840-1880 (Hatfield: University of Hertfordshire Press, 2001); David Bradby, Louis James and Bernard Sharrat, eds., Performance and Politics in Popular Drama (Cambridge: Cambridge University Press, 1980); Elaine Hadley, Melodramatic Tactics: Theatricalized Dissent in the English Market Place, 1800-1885 (Stanford, California: Stanford University Press, 1995); Michael Hays and Anastasia Nikolopoulou, eds. Melodrama: The Cultural Emergence of a Genre (Basingstoke: MacMillan, 1999); Jane Moody, Illegitimate Theatre in London, 1770-1840 (Cambridge: Cambridge University Press, 2000).

${ }^{4}$ Walter Benjamin, Illuminations, trans. Hannah Arendt (London: Pimlico, 1999), 232.

5 The Theatrical Inquisitor, cited in R. Leach, Victorian Melodrama (London: Harrap, 1978), 15.

${ }^{6}$ Frank Fay, cited in Robert Hogan and James Kilroy, Laying the Foundations 1902-1904 (Dublin: Dolmen Press, 1976), 31. For another of his excoriating accounts of the audiences of melodrama see "Irish Drama at the Theatre Royal" in Robert Hogan, ed., Towards a National Theatre: The Dramatic Criticism of Frank J. Fay (Dublin: The Dolmen Press, 1970), 20-1.

${ }^{7}$ Hugh McCartan, “Some Backward Glances,” The Capuchin Annual, 1943, 175.

${ }^{8}$ Perhaps the most exhaustively studied epoch of modern Irish history, the Irish Revival was a romantic movement inspired by Ireland's Gaelic culture and history which precipitated an 
extraordinary efflorescence of literary activity and political energy. What Richard Kirkland calls the 'classic Revival narrative' maintains that between the totemic dates of 1891, following the disillusionment felt by the death of Ireland's iconic nationalist leader, Charles Stewart Parnell, to the detonation of the Easter Rising in 1916, nationalist energies were displaced from the political sphere and directed into cultural activity. (Richard Kirkland, “"Dialogues of Despair: Nationalist Cultural Discourse and the Revival in the North of Ireland, 1900-20," Irish University Review 33.1 (March 2003): 68.

${ }^{9}$ Brooks, xvii.

${ }^{10}$ Frank Fay, cited in Paige Reynolds, Modernism, Drama, and the Audience for Irish Spectacle (Cambridge: Cambridge University Press, 2007), 28.

${ }^{11}$ George Moore, Impressions and Opinions (New York: Charles Scribner's Sons, 1891), 181.

${ }^{12}$ W. B. Yeats, in George Bornstein and Hugh Witemeyer, eds. Letters to the New Island (New York: Macmillan, 1989), 36.

${ }^{13}$ W.B. Yeats, cited in Ann Saddlemyer, "Stars of the Abbey's Ascendancy," in Robert O'Driscoll, ed. Theatre and Nationalism in Twentieth-Century Ireland (Toronto: University of Toronto Press, 1971), 30.

${ }^{14}$ Dublin's Queen's Royal Theatre (1844-1969) in Brunswick Street, (today called Pearse Street), promoted itself as the "Home of Irish Drama" in the 1890s and 1900s given its long-standing commitment to staging annual seasons of Irish work which were mostly melodramas. Its audiences were widely acclaimed - and indicted - for being wildly excitable and noisy. Its whole-hearted embrace of working class audiences and the traditions of the popular stage, not to mention its cheap ticket prices, were in sharp contrast to the rarefied pretentions of the Irish Literary Theatre and their cultivation of a more sedate, sophisticated and wealthy audience base.

${ }^{15}$ Lady Gregory, Our Irish Theatre: A Chapter of Autobiography (New York: G. Putnam's Sons, The Knickerbocker Press, 1913), 8-9.

16 Hugh Hunt, The Abbey: Ireland's National Theatre, 1904-1979 (Dublin: Gill \& Macmillan, 1979), 5.

${ }^{17}$ Christopher Fitz-Simon, Mr J. Kennedy Miller's Very Capable Company of Irish Players (Dublin: Dublin City Public Libraries, 2011), 16. Other works by Hubert O'Grady, and later by Ira Allen and P.J. Bourke, were also immensely popular ${ }^{18}$ Christopher Fitz-Simon, Mr J. Kennedy Miller's Very Capable Company, 11. 
${ }^{19}$ See Jacky Bratton, New Readings in Theatre History (Cambridge: Cambridge University Press, 1993); Tom Postlewait, "From Melodrama to Realism: The Suspect History of American Drama," in Melodrama: The Cultural Emergence of a Genre, eds. Michael Hays, Anastasia Nikolopoulou (Basingstoke: Palgrave Macmillan, 1999), 39-60.

${ }^{20}$ Stephen Watt, Joyce, O'Casey, and the Irish Popular Theatre (Syracuse: Syracuse University Press, 1991) and "Late Nineteenth-Century Irish Theatre: Before the Abbey and Beyond," in The Cambridge Companion to Twentieth Century Irish Drama, ed. Shaun Richards (Cambridge: Cambridge University Press, 2004), 18-32; Nicholas Grene, The Politics of Irish Drama: Plays in Context from Boucicault to Friel (Cambridge: Cambridge University Press, 1999); Cheryl Herr, For the Land They Loved: Irish Political Melodrama, 1890-1925 (Syracuse: Syracuse University Press, 1991); Mary Trotter, Ireland's National Theatres: Political Performance and the Origins of the Irish Dramatic Movement (Syracuse: Syracuse University Press, 2001). Furthermore, recent productions of popular melodramas by Druid Theatre, Galway as well as the National Theatre (both Abbey and Peacock stages) and the Project, testify to the resurgence of interest in melodrama, as Irish theatre practitioners and producers have also played a vital role in recuperating this vital theatre tradition. Notable recent productions at the Abbey Theatre include: Ken Bourke's metatheatrical melodrama, The Hunt for Red Willie (2000); Stewart Parker's Heavenly Bodies (2004) which explored the life, work and legacy of Dion Boucicault whose plays The Colleen Bawn and The Shaughraun, were produced in 1998 and 2004 by John McColgan, of Riverdance fame and were later reprised due to popular demand. Also at the Abbey were two productions of Arrah-na-Pogue in 2010 and 2011. Beyond the Abbey there have been significant productions of Boucicault's The Colleen Bawn by Bedrock in 2010 and by Druid, in 2013.

21 The Freeman's Journal, 7 April 1902, cited in Hogan and Kilroy, Laying the Foundations, 21.

${ }^{22}$ The aisling refers to a genre of poetry in which Ireland is personified in the female form, whether in the shape of a beautiful girl or an old woman.

${ }^{23}$ Christopher Fitz-Simon, "Buffoonery and Easy Sentiment": Popular Irish Plays in the Decade Prior to the Opening of the Abbey Theatre (Dublin: Carysfort Press, 2011).

${ }^{24}$ D.A. Reid, "Popular Theatre in Victorian Birmingham," in Performance and Politics in Popular Drama, eds. D. Bradby, L. James, B. Sharratt (Cambridge: Cambridge University Press, 1980), 82. 
${ }^{25}$ Irish Nights is an appellation I use throughout to describe these particular theatrical events as this appears to be the colloquial, contemporaneous term used by Belfast authors Hugh McCartan and St. John Ervine to describe these particular dramatic occasions.

${ }^{26}$ Marianne Elliott, The Catholics of Ulster (London: Penguin Press, 2000), 321.

27 The Belfast Newsletter, 18 July 1849, cited in A History of Ulster, Jonathan Bardon (Belfast: Blackstaff, 1992), 306.

${ }^{28}$ Cited in Denis Ireland, "Books and Writers In North-East Ulster," in The Bell 4:5 (August 1942): 319.

${ }^{29}$ This term, describing the territorial, tribal fault-lines of sectarian conflict in Belfast's warring ghettoes was first used by Frankfurt Moore, cited in The Narrow Ground: Aspects of Ulster 1609-1969, A.T.Q. Stewart (Belfast: Blackstaff Press, 1977), 143-5.

${ }^{30}$ Cited in John Gray, "Culture and Arts in the North of Ireland Since 1891," in A Century of Northern Life, ed. Eamon Phoenix (Belfast: Ulster Historical Foundation, 1995), 165.

${ }^{31}$ Denis Ireland, From the Irish Shore (London: Rich \& Cowan, 1936), 1.

32 Denis Ireland, "Stuffed Duck in your Fanlight: A Note on the Humour of Belfast," in Now in Ulster, eds. Arthur Campbell and George Campbell (Belfast: Campbell Bros, 1944), 52.

${ }^{33}$ Samuel M. Elliott, The World As I Found It (Belfast: William Brown, 1887), 23.

${ }^{34}$ The Irish News, 1 April 1906, 4.

${ }^{35}$ Nomads’ Weekly, 5 April 1905, 176.

${ }^{36}$ Nomads' Weekly, 11 March 1899, 64.

${ }^{37}$ Reverend O'Hanlon, Walks Among the Poor in Belfast (Wakefield: S.R. Publishers, 1971), 9.

${ }^{38}$ Whitford Kane, Are We All Met? (London: Elkin, Mathews and Marrot, 1931), 46-7.

${ }^{39}$ See Michael R. Booth, "Irish Landscape in the Victorian Theatre," in Place, Personality and the Irish Writer, ed. Andrew Carpenter (Gerrard's Cross: Colin Smythe, 1977), 159172.

${ }^{40}$ Peter Brooks argues that political and revolutionary rhetoric is essentially melodramatic, not only because of its fiery excess and flamboyant extravagance, but because its formal construction is articulated in direct opposition to another system of beliefs, see The Melodramatic Imagination.

${ }^{41}$ Cited in Bram Stoker, Personal Reminiscences of Henry Irving, vol. 1 (London: William Heinemann, 1906), 138.

${ }^{42}$ Mc Cartan, 175. 
${ }^{43}$ Ervine, 14-15.

${ }^{44} \mathrm{McCartan}, 175$.

${ }^{45}$ Bob Blaisdell, ed. Irish Verse: An Anthology (Mineoloa: Dover Publications, 2002), 84.

${ }^{46}$ McCartan, 175.

${ }^{47}$ McCartan, 175.

${ }^{48}$ McCartan, 175.

${ }^{49}$ McCartan, 174.

${ }^{50}$ Michael Booth, English Melodrama (London: Herbert Jenkins, 1965), 33.

${ }^{51}$ J.W. Whitbread, Lord Edward; or "98 in For the Land they Loved, 168.

${ }^{52}$ Lord Edward, 168-9.

${ }^{53}$ Lord Edward, 169.

54 The Irish Playgoer, 19 April 1900, 14.

${ }^{55}$ McCartan, 175.

56 The North experienced three Home Rule crises: the first two were in 1886 and 1893 when, in response to prolonged political campaigns from Irish nationalists, bills were introduced to create an Irish legislature responsible for domestic affairs. These developments in turn provoked "frenzied parliamentary and propagandist campaigns," and the paramilitary mobilisation of Orange Order David Fitzpatrick, The Two Irelands: 19121939 (Oxford: Oxford University Press, 1998), 12. These massive mobilisations of unionism, with the assistance of the Tory party, were ultimately successful with the House of Lords voting against the second bill and smashing Gladstone's divided Liberal party in the 1895 election to usher in a decade of Tory rule. Gladstone returned to power in 1906, but - only recently restored from the ravages of the last bill - had no intention of reviving the issue that so nearly destroyed them. In the 1910 general election, however, a hung parliament left his governing Liberal party dependent on the Irish Parliamentary Party (IPP) to form a new administration; their support subsequently secured on the promise of a third Home Rule Bill. These dramatic political developments precipitated the 'Ulster Crisis', which over the next two years left the North, and indeed Ireland, on the brink of bloody civil war. Although the House of Lords again rejected the bill, their veto, under the 1911 Parliament Act passed specifically for this purpose, was but temporary with Home Rule set to become law in 1914. The deferral of what was essentially a constitutional fait-accompli, fomented a revolutionary atmosphere in the North with the Ulster Volunteer Force (UVF) founded on the premise that 'Ulster will fight and Ulster will be Right' and over half a 
million Northern unionists signed 'Ulster's Solemn League and Covenant' in 1912, committing themselves to use 'all means which may be found necessary' to defeat Home Rule, even if this meant armed resistance against the laws and forces of the British government. The advent of World War 1 is regarded as preventing Ireland from sliding into imminent civil war.

${ }^{57}$ See A. C. Hepburn, A Past Apart: Studies in the History of Catholic Belfast, 1850-1950 (Belfast: Ulster Historical Foundation, 1996); Marianne Elliot, The Catholics of Ulster (London: Penguin, 2000).

${ }^{58}$ Lord Edward, 168.

${ }^{59}$ Ervine, 27.

${ }^{60}$ Watt, 81.

${ }^{61}$ W. J. Lawrence, Barry Sullivan (London: W. \& G. Baird, 1893), 65.

62 Jacky Bratton, "The Contending Discourses of Melodrama," in Melodrama: Stage, Picture, Screen, eds. Jacky Bratton, Christine Gledhill, Jim Cook (London: British Film Institute, 1994), 38-9.

${ }^{63}$ A. Boyd, Holy War in Belfast (Tralee: Anvil, 1970); Mark Doyle, "Fighting Like the Devil for the Sake of God: Protestants, Catholics and the Origins of Violence in Victorian Belfast (Manchester: Manchester University Press, 2009); .C. Hepburn, A Past Apart: Studies in the History of Catholic Belfast 1850-1950 (Belfast: Ulster Historical Foundation, 1996) and Catholic Belfast and Nationalist Ireland in the Era of Joe Devlin, 1871-1934 (Oxford: Oxford University Press, 2008); Catherine Hirst, Religion, Politics and Violence in Nineteenth-Century Belfast: The Pound and Sandy Row (Dublin: Four Courts Press, 2002); W. A. Maguire, Belfast: A History (Lancaster: Carnegie, 2009); M. Goldring, Belfast: From Loyalty to Rebellion (London: Lawrence \& Wishart, 1991); Henry Patterson, Class Conflict and Sectarianism: The Protestant Working Class and the Belfast Labour Movement, 18681920 (Belfast: Blackstaff, c1980); Olwen Purdue, ed. Belfast: The Emerging City, 18501914 (Dublin: Irish Academic Press, 2013).

${ }^{64}$ Kane, 46.

${ }^{65}$ Cited in W. J. Lawrence, The Annals of the Old Belfast Stage 1731-1831, unpublished manuscript (Linen Hall Library, Belfast, 1896), 418. 
${ }^{66}$ Tony Bennett, cited in Marvin Carlson, "Audiences and the Reading of Performance," in Interpreting the Theatrical Past: Essays in the Historiography of Performance, eds. Thomas Postlewait and Bruce McConachie (Iowa: University of Iowa Press, 1989), 86.

67 John Gray, Thomas Carnduff: Life \& Writings (Belfast: Lagan Press, 1994), 125. 'The Wearing of the Green' was a rebel ballad which Boucicault customised to enhance its nationalist hue before adding it to Arragh-na-Pogue; later claiming (falsely) that the song was banned throughout the British Empire, see Deirdre McFeely, Dion Boucicault: Irish Identity on Stage, especially Chapter 3 (Cambridge: Cambridge University Press, 2012), 4050.

By. In Belfast, it would have been a well-known party tune and would have proven provocative to Carnduff and his fellow loyalists.

${ }^{68}$ Bram Stoker, Personal Reminiscences of Henry Irving, vol. II (London: The Macmillan Company, 1906), 133-4.

${ }^{69}$ Bram Stoker, Personal Reminiscences of Henry Irving, vol. 1 (London: The Macmillan Company, 1906), 139.

${ }^{70}$ J.R. R. Adams records that there were numerous editions of both plays: Mitchelburne"s Ireland Preserv'd: or the Siege of Londonderry was originally published in 1705 with subsequent editions issued in Belfast in 1744, 1750 and 1759; in Newry 1774 and Strabane 1787; as well as many more "probably... now lost"; with Belfast editions of The Battle of Aughrim in 1767 and 1800; a Newry edition in 1781 and a Strabane edition in 1785, and "because of the nature of the play and the consequent heavy wear and tear there were almost certainly many local editions", Printed Word and the Common Man (Queen's University of Belfast: Institute of Irish Studies, 1987), 70.

${ }^{71}$ G.C. Duggan, The Stage Irishman (London: Longmans, Green \& Co., 1937), 31.

${ }^{72}$ See Niall Ó Ciosáin, Print and Popular Culture in Ireland, 1750-1850 (Dublin: the Lilliput Press, 1997), 112-133; Christopher J. Wheatley, Beneath Ierne's Banners: Irish Protestant Drama of the Restoration and Eighteenth Century (Notre Dame: University of Notre Dame Press, 1999), 63-84.

${ }^{73}$ William Carleton, The Autobiography of William Carleton (London: MacGibbon \& Kee, 1968), 34

${ }^{74}$ William Carleton, "The Battle of Aughrim," in Humours of Irish Life, ed. C.L. Graves (Belfast: Gresham Publishing Company Ltd, 1913), 131-38; 132. 
${ }^{75}$ Elsewhere in this article, Carleton caustically refers to how the world does not extend beyond the parish, "on the chairs...being the seats of honour, were placed the Protestant portion of the audience, because they were the most wealthy and consequently the most respectable, at least in the eyes of the world - by which we mean parish." Humours, 136.

${ }^{76}$ William M. Thackeray, The Irish Sketch Book and Critical Reviews (Philadelphia: J. B. Lippincott \& Co., 1879), 173.

77 The Battle of Scarva, or "the sham fight", is a small scale reconstruction of the Battle of the Boyne performed annually in Scarva, Co. Down on July 13 and is usually the largest attended single event in the loyalist marching season.

${ }^{78}$ It may seem extraordinary that the bloodiest battle ever fought on Irish soil and which destroyed Irish Jacobitism, should be as popular with Catholic readers and audiences as it was with Protestants; a paradox Christopher Wheatley explains in terms of the play's "duality", whereby "seemingly incompatible sympathies are in equipoise, so that both catholics and protestants were attracted to the play for generations." Christopher J. Wheatley, "Heroic Palimpsest: Robert Ashton's The Battle of Aughrim," Eighteenth-Century Ireland, Vol. 11 (1996): 53-73; 54.

${ }^{79}$ Carleton, Humours, 132.

${ }^{80}$ Carleton, Autobiography, 36.

${ }^{81}$ Conor Cruise O’Brien, Writers and Politics (London: Chatto \& Windus, 1965), 13.

${ }^{82}$ Carleton, Humours, 136-7.

${ }^{83}$ Carleton, Humours, 138.

${ }^{84}$ Carleton, Humours, 133.

${ }^{85}$ Carleton, Humours, 133.

86 Rokem, Freddie, Performing History: Theatrical Representations of the Past in Contemporary Theatre (Iowa: University of Iowa Press, 2000), 8.

${ }^{87}$ D.A. Reid, 76.

${ }^{88}$ Mary D. Condon, The Dublin Riots of 1822 (University of Southern California, 1930), 75. The events and aftermath of this particular theatre riot are brilliantly covered in Christopher Morash's A History of Irish Theatre 1601-2000, see p. 94-102.

89 Belfast's colourful, controversial attorney-of-law, John Rea, attempted to hold mass political meetings in local theatres on many occasions. He also selected the theatre as the site in which to challenge a local magistrate during a performance, causing such an uproar that the victim has to be escorted outside. Smithfield theatre was also selected as the venue 
for a Catholic defence committee to hold the inaugural meeting of a Gun Club although police successfully prevented the meeting from taking place. For other riotous assemblies in Belfast playhouses see Mark Phelan, "Modernity, Geography, and Historiography: (Re)Mapping Irish Theatre History in the 19th Century" in The Performing Society: British Theatre in the Nineteenth-Century, eds. Tracy C. Davis and Peter Holland (London: Palgrave, 2007), 135-158.

${ }^{90}$ Morash, 102.

${ }^{91}$ Condon, 85.

${ }^{92}$ Reid, 76.

93 George Moore, The Bending of the Bough (New York: Herbert S. Stone \& Company, 1900), xvi.

94 Beyond scrutiny of the Playboy of the Western World and The Plough and the Stars riots, there has been little sustained examination of the vital issue of audience reception. Though Paige Reynolds' recent study is a hopeful harbinger of further research in this area in future Paige Reynolds, Modernism, Drama, and the Audience for Irish Spectacle (Cambridge: Cambridge University Press, 2007).

95 Loren Kruger, The National Stage: Theatre and Cultural Legitimation in England, France, and America (Chicago: University of Chicago Press, 1992), 4. 